Przegląd Badań Edukacyjnych

ISSN 1895-4308

nr $18(1 / 2014)$, s. 57-74

ORYGINALNE

ARTYKUŁY

BADAWCZE

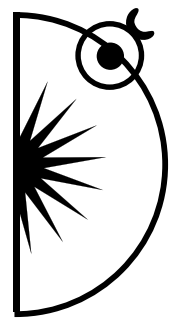

Violetta Kopińska

\title{
Wizerunek młodzieży w dyskursie na temat przestępczości nieletnich w podręcznikach do wiedzy o społeczeństwie na poziomie ponadgimnazjalnym
}

DOI: http://dx.doi.org/10.12775/PBE.2014.005

\section{Wprowadzenie}

Celem niniejszego artykułu jest pokazanie, jaki wizerunek młodzieży i przestępczości jest konstruowany w ramach dyskursów odnoszących się do przestępczości nieletnich zawartych w podręcznikach do wiedzy o społeczeństwie. Przedstawione w niniejszym artykule analizy stanowią fragment szerzej zakrojonych badań dotyczących edukacji prawnej. Punktem wyjścia dla tego artykułu jest założenie, że pomimo zmian w zakresie sposobu określania kompetencji obywatelskich dominujący w zakresie edukacji prawnej jest model normatywno-deterministyczny (Borucka-Arctowa, Skąpska, 1993, s.13), a dominującą koncepcja prawa jest koncepcja pozytywistyczna (Czarnota, 2006, s. 23; Kopińska, 2012, s. 188-196). Konsekwencją przyjęcia takiego założenia jest hipoteza na temat koncentracji na kompetencjach adaptacyjnych w ramach instytucjonalnej edukacji prawnej. W myśl tej hipotezy aktywność obywatelska jest pożądana, ale tylko w zakresie uczestnictwa w rozwiązywaniu różnego rodzaju problemów społecznych. W ramach procesów związanych z funkcjonowaniem prawa aktywność sprowadzana jest natomiast do aktu wyborczego. Uproszczo- 
ny, schematyczny czy wręcz dogmatyczny obraz prawa wyklucza kompetencje krytyczne i emancypacyjne obywateli w sferze tworzenia, zmieniania, rozwijania, stosowania prawa. Dyskursy budowane w tym obszarze muszą mieć zatem charakter utrwalający, bo inaczej - zgodnie z przyjętą logiką - grozi nam chaos i anarchia.

Należy się zatem spodziewać, że wizja świata tworzona w ramach podręczników szkolnych dotykających edukacji prawnej (doskonałym przykładem są tu podręczniki do przedmiotu Wiedza o społeczeństwie) będzie narzucała określone rozumienie prawa i stosunku człowieka do prawa. Jeżeli podręcznik stanowi nie tylko konkretyzację określonych w danym państwie treści kształcenia i wymagań, które konstruowane są w odniesieniu do uczniów i uczennic na poszczególnych etapach edukacyjnych, ale jest także tekstem kultury (Chomczyńska-Rubacha, Pankowska, 2011, s.17-30), oznacza to, że dyskursy dominujące w podręcznikach dają nam pewną wiedzę o rzeczywistości społecznej. Za M. Reisiglem przyjmuję, że dyskursy to wieloperspektywiczne semiotyczne wiązki praktyk społecznych składające się $\mathrm{z}$,wzajemnie powiązanych równoczesnych i sekwencyjnych działań językowych oraz innych działań semiotycznych, które konstytuują rzeczywistość społeczną i są przez nie konstytuowane" (Reisigl, 2010, s. 36). Stanowią wiedzę o różnych aspektach rzeczywistości, zasoby dla jej reprezentacji, a przez to - ramę dla nadawania sensu tej rzeczywistości, choć - rzecz jasna - nie determinuja jej w sposób całkowity (Van Leeuwen, 2005, s. 95). Według T. van Leeuwena dowodem na istnienie danego dyskursu jest w szczególności podobieństwo, które wynika z różnych tekstów, a dotyczy tego samego aspektu rzeczywistości (Van Leeuwen, 2005, s. 95). Krytyczna analiza dyskursu pozwala natomiast na identyfikację określonych strategii dyskursywnych i schematów argumentacyjnych, za pomocą których określona rzeczywistość jest konstruowana.

Płaszczyzną, która stanowi punkt zainteresowania w ramach niniejszego artykułu jest przestrzeganie prawa. Wybór tej płaszczyzny jest implikacją przyjętych tu założeń. Deterministyczne pojmowanie prawa pozwala sądzić, że esencją dyskursu utrwalającego w zakresie edukacji prawnej będzie nie tworzenie, zmienianie, rozwijanie czy stosowanie prawa - ale właśnie jego przestrzeganie.

\section{Uwagi metodologiczne}

Dokonując krytycznej analizy dyskursów podręczników do wiedzy o społeczeństwie na poziomie ponadgimnazjalnym, w niniejszym artykule poszukiwano odpowiedzi na następujące pytania: 
1. W jaki sposób konstruowany jest wizerunek młodzieży w tekstach odnoszących się do przestępczości nieletnich? (nominalizacja)

2. Jakie cechy pozytywne/negatywne przypisywane są młodym ludziom w analizowanych tekstach? (predykacja)

3. Za pomocą jakich argumentów próbuje się uzasadnić ewentualne przykłady orzekania? (argumentacja)

4. Czy w analizowanych tekstach obecne są wzmocnienia lub tonowanie (wzmacnianie/tonowanie)?

Powyższe pytania wskazują na analizę dyskursu pod kątem strategii dyskursywnych wyróżnionych przez M. Reisigla (2011), R. Wodak (2001, s. 150-183). Strategia dyskursywna natomiast jest tu rozumiana jako mniej lub bardziej właściwy i intencjonalny plan działań zastosowanych po to, by osiągnąc dany cel społeczny, polityczny, psychologiczny, lingwistyczny (ibidem). Wskazując środki stosowane w ramach określonych strategii dyskursywnych, odwołano się również do klasyfikacji praktyk społecznych, blokujących rozwój twórczej osobowości, autorstwa Wiesława Łukaszewskiego (1984, s. 469-505).

Korpus badawczy został stworzony w oparciu o jeden gatunek - podręcznik szkolny, tu: podręcznik do wiedzy o społeczeństwie na poziomie ponadgimnazjalnym.

W korpusie badawczym, który stanowi podstawę analiz zawartych w tym artykule znalazło się pięć spośród siedmiu dopuszczonych do użytku szkolnego podręczników do wiedzy o społeczeństwie dla czwartego etapu edukacyjnego na poziomie podstawowym:

- Zbigniew Smutek, Jan Maleska, Wiedza o spoleczeństwie, podręcznik dla szkót ponadgimnazjalnych. Zakres Podstawowy, Operon 2013;

- Arkadiusz Janicki, W centrum uwagi, Podręcznik do wiedzy o spoteczeństwie dla szkól ponadgimnazjalnych, Zakres podstawowy, Wydawnictwo Nowa Era, Warszawa 2012;

- Katarzyna Fic, Maciej Fic, Lech Krzyżanowski, Wiedza o społeczeństwie. Podręcznik dla szkót ponadgimnazjalnych. Zakres podstawowy, SOP Oświatowiec Sp. z o.o., Toruń 2012;

- Iwona Walendziak, Mikołaj Walczyk, Wiedza o społeczeństwie dla szkót ponadgimnazjalnych, Podręcznik z ćwiczeniami, Zakres podstawowy, Wydawnictwo Edukacyjne Zofii Dobkowskiej „Żak”, Warszawa2012;

- Marek Grondas, Janusz Żmijski, Po prostu WOS. Wiedza o społeczeń- 
stwie. Zakres podstawowy. Podręcznik dla szkół ponadgimnazjalnych, WSiP, Warszawa $2012^{1}$.

Do analizy wybrano teksty dotyczące przestępczości młodzieży. Wybór tematu został podyktowany kilkoma czynnikami. Po pierwsze - tematyka ta jest wpisana w zakres podstaw programowych do kształcenia w ramach przedmiotu Wiedza o społeczeństwie na czwartym etapie edukacyjnym. Po drugie - temat przestępczości pozostaje w ścisłym związku z płaszczyzną przestrzegania prawa. Po trzecie - wcześniejsze szersze analizy dyskursów podręcznikowych, prowadzone w związku z badaniami nad edukacją prawna, pozwoliły na wstępną identyfikację podobieństw odnoszących się do cech wizerunku młodzieży i przestępczości, posługiwania się stereotypami w odniesieniu do przestępczości nieletnich, straszenia i grożenia. Podobieństwa te wskazują na istnienie określonych dyskursów. Ich pogłębiona analiza stanowi zatem zasadniczą cześć niniejszego artykułu.

\section{Analiza strategii dyskursywnych}

Kontekst konstruowania wizerunku młodzieży w ramach analizowanych tekstów został wyznaczony ich typem. W związku z tematyką ich cechą charakterystyczną było mówienie o młodych ludziach w kategoriach sprawców lub ofiar przestępstw. Rzecz jasna, styczność współczesnego człowieka z przestępstwem wykracza poza dychotomię sprawca-ofiara, niemniej jednak eksponowanie tej dychotomii można uznać w pewnym stopniu za uzasadnione jako odwoływanie się do przykładów niosących ze sobą szczególne niebezpieczeństwa. Należy jednak przy tym pamiętać, jaka jest różnica między sprawcą i ofiarą przestępstwa. Sugerowanie, że młodzi ludzie, którzy są lub mogą być ofiarami, są współwinni popełnienia przestępstwa, jest zabiegiem dyskryminującym;

Warto zwrócić uwagę na fakt, że bardzo często młodzi ludzie nieświadomie pomagają przestępcom, podając zbyt wiele poufnych lub delikatnych informacji na forach i w blogach.[5P]

W analizowanych fragmentach podręczników całkowicie pominięto natomiast kwestię bycia świadkiem przestępstwa lub też problematykę zachowania się w sytuacji, w której istnieje uzasadnione podejrzenie, że zostało popełnione przestępstwo. Rozwijanie kompetencji uczniów i uczennic w tym zakresie wydaje się równie ważne jak wiedza o konsekwencjach popełnianych czynów, czy też wiedza o prawach przysługujących ofiarom przestępstw lub środkach

${ }^{1} \mathrm{~W}$ dalszej części artykułu podręczniki oznaczono symbolami od [1P] do [5P], w przypadkowej kolejności. 
ostrożności podejmowanych po to, by uniknąć określonych sytuacji. Dyskurs podręcznikowy natomiast milczy na ten temat. Nie oznacza to wszakże, że tematyka ta nie jest w ogóle poruszana w analizowanych podręcznikach. Należy jednak podkreślić, że jest jedynie wzmiankowana i łączona $\mathrm{z}$ wizerunkiem dorosłych lub z wizerunkiem określonych organów. $\mathrm{W}$ odniesieniu do młodzieży charakterystyczna jest dychotomia sprawca-ofiara.

Konstruowany wizerunek młodzieży w badanych tekstach nacechowany jest generyzacją. Stosowane określenia „młodzież” oraz „nieletni” w połączeniu z kontekstem analizowanych tekstów oraz ze strategią orzekania, za pomocą której grupa ta jest wyraźnie negatywnie wartościowana, prowadzi do generalizacji i stereotypizacji. Stosowanie prawnego pojęcia „nieletni” (które nie jest tożsame z pojęciem „niepełnoletni”) bez jego wyraźnego zdefiniowania i przypisanego mu zakresu stosowania jest $\mathrm{w}$ rezultacie zabiegiem depersonalizującym, a jednocześnie - stwarzającym pozory bycia synonimem kategorii „młodzież”.

Podstawowym elementem konstrukcji wizerunku młodzieży jest szerząca się przestępczość w tej grupie, która jest silnie eksponowana przez zastosowanie różnego rodzaju strategii dyskursywnych.

Tabela 1. Strategie dyskursywne w tekstach na temat przestępczości-podręczniki WOS, etap ponadgimnazjalny, zakres podstawowy

\begin{tabular}{|c|c|c|c|}
\hline Lp. & Przykład & $\begin{array}{c}\text { Strategia } \\
\text { dyskursywna }\end{array}$ & Środki \\
\hline 1. & $\begin{array}{l}\text { Poważnym problemem wśród młodzieży jest wysoki } \\
\text { poziom przestępczości nieletnich (13 - } 16 \text { lat). Mimo } \\
\text { niewielkiego spadku w } 2008 \text { roku już w następnym } \\
\text { w tej grupie wiekowej odnotowano ponad } 85 \text { tys. } \\
\text { czynów karalnych, co jest największą liczba w ciągu } \\
20 \text { lat [2P]. } \\
\text { Dalej tekst wskazuje dane z } 2000 \text { oraz 2008-2009 } \\
\text { roku odnoszące się do popełnienia przez nieletnich } \\
\text { konkretnych czynów karalnych (spowodowane } \\
\text { uszczerbku na zdrowiu, liczba bójek i pobić z udziałem } \\
\text { nieletnich, liczba czynnych napaści nieletnich na funk- } \\
\text { cjonariuszy publicznych - dane wskazują na wzrost). }\end{array}$ & $\begin{array}{l}\text { Nominalizacja } \\
\text { predykacja, } \\
\text { argumentacja, } \\
\text { wzmacnianie }\end{array}$ & $\begin{array}{l}\text { Synekdocha totum } \\
\text { pro parte, stereoty- } \\
\text { pizacja, } \\
\text { Blokada informacji, } \\
\text { manipulowanie infor- } \\
\text { macjami, argumenta- } \\
\text { cja za pomocą danych } \\
\text { statystycznych }\end{array}$ \\
\hline 2. & $\begin{array}{l}\text { Wzrasta również liczba zdemoralizowanej młodzieży. } \\
\text { Jej zachowanie nie narusza wprawdzie obowiązują- } \\
\text { cego prawa, ale jest sprzeczne z uniwersalnym sys- } \\
\text { temem wartości i normami moralno-obyczajowymi. } \\
\text { W } 2008 \text { roku wobec } 23923 \text { nieletnich orzeczono } \\
\text { środki wychowawcze w związu z demoralizacją (czy- } \\
\text { ny zabronione, używanie alkoholu lub środków odu- } \\
\text { rzających, włóczęgostwo i udział w grupach przestęp- } \\
\text { czych). Dla porównania w } 2000 \text { roku nadzorem objęto } \\
10169 \text { nieletnich. [2P] }\end{array}$ & $\begin{array}{l}\text { Predykacja, } \\
\text { argumentacja } \\
\end{array}$ & $\begin{array}{l}\text { Stereotypizacja, } \\
\text { blokada informacji, } \\
\text { manipulowanie infor- } \\
\text { macjami, argumenta- } \\
\text { cja za pomocą danych } \\
\text { statystycznych }\end{array}$ \\
\hline
\end{tabular}


Tabela 1. Cd.

\begin{tabular}{|c|c|c|c|}
\hline 3. & $\begin{array}{l}\text { Najbardziej niepokojącym zjawiskiem patologicznym } \\
\text { wśród młodzieży jest narkomania. [2P] } \\
\text { Dalej wskazuje się na liczbę przestępstw popełnionych } \\
\text { przez nieletnich z zakresu ustawy o przeciwdziałaniu } \\
\text { narkomanii w odniesieniu do liczby przestępstw po- } \\
\text { pełnianych przez dorosłych oraz określone wyniki ba- } \\
\text { dań przeprowadzonych przez CBOS dotyczące wiedzy } \\
\text { na temat miejsc nabywania narkotyków oraz deklara- } \\
\text { cji uczniów co do zażycia przynajmniej raz marihuany } \\
\text { lub haszyszu. }\end{array}$ & $\begin{array}{l}\text { Nominalizacja, } \\
\text { Predykacja }\end{array}$ & $\begin{array}{l}\text { Synekdocha totum } \\
\text { pro parte, stereoty- } \\
\text { pizacja, manipulacja } \\
\text { informacjami }\end{array}$ \\
\hline 4. & $\begin{array}{l}\text { Picie alkoholu sprzyja popełnianiu czynów zabronio- } \\
\text { nych. W } 2009 \text { roku } 12 \% \text { nieletnich uczestników bójek } \\
\text { było nietrzeźwych. [2P] }\end{array}$ & $\begin{array}{l}\text { Predykacja, argumen- } \\
\text { towanie }\end{array}$ & $\begin{array}{l}\text { Stereotypizacja, } \\
\text { Argumentacja za } \\
\text { pomocą danych } \\
\text { statystycznych, blo- } \\
\text { kowanie informacji, } \\
\text { manipulowanie } \\
\text { informacjami }\end{array}$ \\
\hline 5. & $\begin{array}{l}\text { Jednym z najbardziej niepokojących ostatnio zjawisk } \\
\text { jest wzrost liczby przestępstw uznawanych za szcze- } \\
\text { gólnie niebezpieczne dla życia i zdrowia (zabójstwa, } \\
\text { uszkodzenia ciała, bójki, pobicia, zgwałcenia, rozboje, } \\
\text { wymuszenia rozbójnicze). Nieletni sprawcy w swoich } \\
\text { przestępczych działaniach są coraz bardziej agresyw- } \\
\text { ni, bezwzględni i okrutni. Wynika to głównie z faktu, } \\
\text { że najczęściej działają w grupach i pod wpływem al- } \\
\text { koholu. } \\
\text { (...) } \\
\text { Kolejnym niepokojącym zjawiskiem jest gwałtowny } \\
\text { wzrost przestępczości wśród nieletnich dziewcząt [3P] } \\
\text { Dalej tabele z danymi pokazujące zestawienia podej- } \\
\text { rzanych o popełnienie przestępstwa w } 1999 \text { i 2009 } \\
\text { roku z podziałem na płeć. Pod tabelą polecenia: } \\
\text { Powołując się na dane umieszczone w tabelach, uza- } \\
\text { sadnij następujące tezy: } \\
\text { - w latach } 1999-2010 \text { liczba podejrzanych dziewcząt } \\
\text { w wieku do } 16 \text { lat rosła szybciej niż chłopców } \\
\text { - podobną tendencję można zaobserwować wśród po- } \\
\text { dejrzanych dziewcząt w kategorii wiekowej } 17-20 \text { lat } \\
\text { - wzrost liczby podejrzanych o popełnienie tych prze- } \\
\text { stępstw dziewcząt w obu kategoriach wiekowych jest } \\
\text { wyższy niż wśród ogółu kobiet [3P] }\end{array}$ & $\begin{array}{l}\text { Predykacja, } \\
\text { Argumentacja, } \\
\text { wzmacnianie } \\
\\
\end{array}$ & $\begin{array}{l}\text { Stereotypizujące } \\
\text { przypisywanie cech } \\
\text { negatywnych, } \\
\text { argumentowanie } \\
\text { poprzez odwoływanie } \\
\text { się danych statystycz- } \\
\text { nych, } \\
\text { sugerowanie }\end{array}$ \\
\hline 6. & $\begin{array}{l}\text { Prawie } 80 \% \text { czynów karalnych dokonywanych przez } \\
\text { nieletnich stanowią kradzież kradzieże z włamania- } \\
\text { mi, bójki i pobicia oraz różne przestępstwa związane } \\
\text { z narkotykami Przestępczość taka koncentruje się prze } \\
\text { wszystkim w miastach (najbardziej niebezpieczne są uli- } \\
\text { ce, blokowiska, tereny obiektów handlowych, salonów } \\
\text { gier, szkół, okolic dworców, przystanków komunikacji } \\
\text { miejski itp.). Nasila się wraz z gwałtownym rozwojem } \\
\text { ośrodków miejskich oraz uprzemysłowieniem kraju. } \\
\text { Często towarzyszy postępowi, technicznemu. [4P] }\end{array}$ & Predykacja & $\begin{array}{l}\text { Stereotypizacja, } \\
\text { blokowanie infor- } \\
\text { macji, manipulacja } \\
\text { informacjami }\end{array}$ \\
\hline
\end{tabular}


Tabela 1. Cd.

\begin{tabular}{|c|c|c|c|}
\hline 7. & $\begin{array}{l}\text { Poważnym problemem III Rzeczypospolitej jest znacz- } \\
\text { ny udział nieletnich w działaniach przestępczych (por. } \\
\text { tabela) } \\
\text { Dalej tabela zawierająca dane liczbowe określające } \\
\text { prawomocnie orzeczone środki wychowawcze, po- } \\
\text { prawcze lub kary w sądach powszechnych wobec nie- } \\
\text { letnich za popełnienie określonych czynów karalnych } \\
\text { (przestępstw). } \\
\text { Pod tabelą polecenie: } \\
\text { (...) Zastanów się, czy zmniejszenie się liczby wyro- } \\
\text { ków za popełnienie konkretnych czynów musi ozna- } \\
\text { czać spadek ich popełniania [5P] }\end{array}$ & $\begin{array}{l}\text { Predykacja, } \\
\text { Argumentowanie, } \\
\text { wzmacnianie/ tono- } \\
\text { wanie } \\
\\
\end{array}$ & $\begin{array}{l}\text { Argumentowanie za } \\
\text { pomocą danych staty- } \\
\text { stycznych, manipulo- } \\
\text { wanie informacjami, } \\
\text { wzmacnianie } \\
\text { /tonowanie poprze } \\
\text { konstruowanie okre- } \\
\text { ślonych poleceń do } \\
\text { materiału statystycz- } \\
\text { nego }\end{array}$ \\
\hline 8. & $\begin{array}{l}\text { Jako nieletni sprawca czynu karalnego masz prawa } \\
\text { podobne do dorosłych, a jeżeli nie ukończyłeś } 15 \text { lat, } \\
\text { czynności z Twoim udziałem powinny być przeprowa- } \\
\text { dzone w obecności przedstawiciela ustawowego lub } \\
\text { faktycznego opiekuna. Jeżeli takie będzie postano- } \\
\text { wienie organu prowadzącego postępowanie, jesteś } \\
\text { zobowiązany poddać się: oględzinom zewnętrznym } \\
\text { ciała (pobraniu odcisków, fotografowaniu, okazywa- } \\
\text { niu w celach rozpoznawczych innym osobom); musisz } \\
\text { zgodzić się na poddanie różnym badaniom (m.in. po- } \\
\text { łączonym z dokonaniem zabiegów na ciele - pobra- } \\
\text { niu krwi, włosów lub wydziel in organizmu). [5P] }\end{array}$ & $\begin{array}{l}\text { Nominalizacja } \\
\text { Predykacja }\end{array}$ & $\begin{array}{l}\text { Zwracanie się do po- } \\
\text { tencjalnego adresata } \\
\text { podręcznika (ucznia/ } \\
\text { uczennicy w wieku } \\
\text { ponad-gimnazjalnym) } \\
\text { jak do sprawcy czynu } \\
\text { karalnego }\end{array}$ \\
\hline
\end{tabular}

Pierwszy przykład (tab. 1) zawiera przede wszystkim błąd merytoryczny, ponieważ określa mianem nieletnich osoby między 13-16 rokiem życia, co nie jest zgodne z ustawą z dnia 26 października 1982 roku o postępowaniu w sprawach nieletnich (t.j. Dz.U. z 2010, Nr 33, poz. 178 ze zmianami). Przez zastosowanie synekdochy totum pro parte konstruowany jest komunikat, który sugeruje, że problem przestępczości dotyczy całej młodzieży, a nie określonej jej części. Widoczne jest to również w przykładzie 8 (tab.1), który przez zastosowanie drugiej osoby liczby pojedynczej utożsamia adresatów podręcznika ze sprawcami czynów karalnych. Warto przy tym zwrócić uwagę, że co prawda został tu zastosowany tryb przypuszczający, ale nie w kontekście bycia sprawcą czynu karalnego, tylko innych, dodatkowych okoliczności (wiek, ewentualne postanowienie sądu).

Prezentowany w przykładzie pierwszym wizerunek młodzieży jest również wyraźnie negatywnie wartościowany, a zabiegi uzasadniające wydają się wiarygodne dzięki zastosowaniu „obiektywnej” argumentacji. W rzeczywistości nie chodzi jednak o wskazanie realnych rozmiarów omawianego problemu, ale o „dopasowanie" danych do stereotypowego obrazu. Po pierwsze, nie wiadomo, jakie jest źródło danych statystycznych wykorzystywanych do 
argumentacji. Po drugie, mamy tu do czynienia z manipulacją informacjami. Pierwsze zdanie mówi o „wysokim poziomie przestępczości nieletnich”. Drugie odwołuje się do wzrostu liczby „czynów karalnych”. Warto zatem wiedzieć, że pojęcie czynu karalnego stosowane w odniesieniu do nieletnich, obejmuje swym zakresem nie tylko przestępstwa, ale także szereg wykroczeń (art. $1 \S 2$ pkt 2 ustawy o postępowaniu w sprawach nieletnich), a zatem mamy tu do czynienia $\mathrm{z}$ fałszywą argumentacją, która dodatkowo zostaje wzmocniona przez użycie sformułowania „co jest największą liczbą w ciągu 20 lat” . Argumentacja została z pewnością konstruowana na podstawie statystyk policyjnych, które, określając udział nieletnich w przestępczości, zestawiają liczbę czynów karalnych z liczbą przestępstw, co - ze względu na różnice w rozumieniu tych pojęć - jest nieuprawnione (http://statystyka.policja.pl/st/wybrane-statystyki/ przestepczosc-nieletni/50256,dok.html, dostęp: 2014-02-21). Nie thumaczy to jednak faktu posługiwania się $\mathrm{w}$ podręcznikach takimi niepoprawnymi zestawieniami dla uzasadnienia określonej tezy.

Przykład 2 (tab. 1) doskonale wpisuje się w konstruowany stereotypowy wizerunek złej młodzieży. Pomijając kolejny błąd merytoryczny, polegający na wykluczeniu czynów przestępczych z pojęcia demoralizacja ${ }^{2}$, również w tym przypadku mamy do czynienia $\mathrm{z}$ fałszywą argumentacją. Porównanie liczby nieletnich objętych nadzorem z liczbą nieletnich, wobec których orzeczono środki wychowawcze w związku $\mathrm{z}$ demoralizacją, w żadnym razie nie może uprawniać do wysunięcia wniosku o wzrastającej liczbie zdemoralizowanej młodzieży. Nadzór nad nieletnimi jest tylko jednym z przykładów środków wychowawczych, zawartych w art. 6 ustawy o postępowaniu w sprawach nieletnich. Warto również dodać, że nadzór nad nieletnimi może być także stosowany w przypadku popełnienia czynu karalnego. Porównanie wskazanych danych statystycznych jest zatem nielogiczne, choć sprawia wrażenie obiektywnego argumentu. Nie wiadomo również, skąd pochodzą prezentowane dane, co uniemożliwia adresatowi własną ocenę w tym zakresie. Podobny charakter ma argumentacja wykorzystana w przykładzie 4 (tab.1). Tu również nie wskazano źródeł. Poza tym fakt, że „w 2009 roku 12\% nieletnich uczestników bójek było nietrzeźwych", nie uzasadnia tezy, że picie alkoholu sprzyja popełnianiu czynów zabronionych.

${ }^{2}$ Co prawda ustawa o postępowaniu w sprawach nieletnich rozróżnia kwestię zapobiegania i zwalczania demoralizacji od postępowania w sprawach o czyny karalne, ale ma to znaczenie w kontekście wieku dziecka i łączy się z możliwością lub brakiem możliwości orzekania określonych środków wychowawczych i poprawczych. Warto także dodać, że art. 4 §1 ww. ustawy wśród przejawów demoralizacji wymienia popełnianie czynu zabronionego 
Na poparcie kolejnej wartościującej tezy (przykład 3 - tab. 1) użyte zostały również argumenty oparte na danych statystycznych. Na pierwszy rzut oka nie budzą one wątpliwości, ale bardziej szczegółowa analiza rodzi wiele pytań. Pierwszy i zasadniczy zarzut polega na tym, że teza o „najbardziej niepokojącym zjawisku patologicznym wśród młodzieży" została skonstruowana m.in. na podstawie statystyk nieodnoszących się wcale do liczby osób (w tym nieletnich), które w określonym roku popełniły przestępstwa „narkotykowe”, ale liczby podejrzanych o popełnienie tego typu przestępstw. Po drugie, argumenty wskazane w tekście nie są wystarczające do tego, by móc stwierdzić, że narkomania jest najbardziej niepokojącym zjawiskiem patologicznym wśród młodzieży. Wreszcie - po trzecie, przestępstwa z zakresu ustawy o przeciwdziałaniu narkomanii mają zróżnicowany charakter - od posiadania narkotyków do handlu, wytwarzania, wprowadzania ich do obrotu. Objęcie ich jedną kategorią ma swoje uzasadnienie prawne (to samo źródło prawa), ale implikuje zasadniczą wątpliwość; czy udział nieletnich w poszczególnych typach przestępstw z zakresu ustawy o przeciwdziałaniu narkomanii jest taki sam lub podobny, niezależnie od rodzaju przestępstwa? Z podobną sytuacją mamy do czynienia w przykładzie 6 (tab.1), w którym mówi się o różnych przestępstwach zwiazanych z narkotykami, nie precyzując tego w żaden sposób i nie odwołując się do żadnych źródeł w tym zakresie, które umożliwiałyby sprawdzenie, o jakie przestępstwa zasadniczo chodzi. Tak ogólna argumentacja, oparta na wybiórczych danych statystycznych może być myląca.

Ze stereotypizującymi, negatywnymi predykatami mamy też do czynienia w przykładzie 5 (tab. 1). Nieletnich przedstawia się tu jako coraz bardziej agresywnych, bezwzględnych i okrutnych, najczęściej pod wpływem alkoholu. W tekście, który dotyczy przestępczości nieletnich, pojawiają się również ujęte w formie tabeli dane statystyczne na ten temat. Tym razem podano źródło tych danych. Niestety jednak sposób przedstawienia danych wprowadza w błąd. Tabela zatytułowana „Przestępczość nieletnich w latach 1990-2010” obejmuje również ogólną liczbę przestępstw popełnionych w poszczególnych latach, przy czym nie zostało wyraźnie zaznaczone, że nie chodzi tu tylko o nieletnich, co biorąc pod uwagę tytuł tabeli, wprowadza w błąd. Taki sposób prezentacji danych jest mylący i z pewnością trudny do odczytania, a w konsekwencji nie pozwala na wyciaganie adekwatnych wniosków. Dalej, ten sam tekst zwraca uwagę na wzrost przestępczości nieletnich dziewcząt. Teza zostaje wzmocniona przez zastosowanie określenia „gwałtowny”. Argumentacja natomiast zostaje przedstawiona w postaci danych statystycznych, które: po pierwsze - nie odnoszą się tylko do nieletnich dziewcząt, ale również do młodych kobiet, a po 
drugie - co jest kluczem dla oceny merytorycznej siły użytych argumentów wskazują na liczby osób podejrzanych o popełnienie przestępstwa. W tekście zatem sugeruje się, że liczba osób popełniających przestępstwa jest tożsama z tymi, którzy są podejrzewani o ich popełnienie. Warto przy tym dodać, że polecenia, które zostały umieszczone pod tabelami, zniekształcają obraz przestępczości, ponieważ kierują uwagę na wzrost liczby podejrzanych o popełnienie przestępstwa dziewcząt i kobiet, pomijając fakt dominującej wciąż liczby chłopców i młodych mężczyzn podejrzewanych o popełnienie przestępstw. Polecenia mają zatem charakter jednostronny i manipulacyjny po to, by wyeksponować określony wizerunek problemu.

Argumentacji opartych na danych statystycznych z jednoczesnym podaniem źródła tych danych użyto w ramach przykładu 7 (tab.1). Niestety i w tym przypadku stworzono jedynie pozory rzetelności. Przedstawione tam dane nie wskazuja udziału nieletnich w działaniach przestępczych, tylko liczbę popełnionych przez nich poszczególnych czynów. Nadto z tabeli wynika, że w przypadku niektórych przestępstw (kradzież z włamaniem, rozbój, zabójstwo, wymuszenie rozbójnicze) we wskazanych latach nastapił spadek. Wniosek ten „koryguje” polecenie pod tabelą. Ma ono z jednej strony charakter wzmacniający, jeżeli rozpatrujemy je w odniesieniu do wcześniejszej skonstruowanej tezy o znacznym udziale nieletnich $w$ działaniach przestępczych. $\mathrm{Z}$ drugiej natomiast strony polecenie to tonuje wnioski, które pojawiają się po analizie danych w tabeli. Tak czy inaczej, konstrukcja polecenia zwraca nas w kierunku wcześniej postawionej tezy, sugerując, że zmniejszenie liczby wyroków za popełnienie określonych czynów wcale nie oznacza w tym przypadku zmniejszenia liczby popełnianych przestępstw.

Tylko w dwóch badanych podręcznikach ([3P] i [1P]) zwraca się uwagę na środowiskowe uwarunkowania przestępczości nieletnich. Niestety i w tych przypadkach mamy do czynienia z brakiem źródeł, które uzasadniają określone tezy oraz/lub ze stereotypowym ujmowaniem problemu, np.:

\footnotetext{
„W kontekście zagrożenia przestępczością najważniejsza jest odpowiedź na pytanie, na ile wartości i styl życia jakiejś grupy [subkulturowej - przyp. V.K.] zachęcają do zachowań narażających na stanie się ofiarą przestępstwa lub do naruszania prawa. Wedle obiegowych opinii ideologia skinheadów wiąże się z nienawiścią rasową i skłonnością do zachowań agresywnych wobec mniejszości etnicznych lub obyczajowych, szalikowcy kojarzeni są z zachowaniami chuligańskimi i piciem alkoholu, skejci i rastafarianie - z zażywaniem niektórych narkotyków. Te uproszczone klasyfikacje mogą jednak okazać się mylące lub nawet niesprawiedliwe w odniesieniu do ciebie lub twoich znajomych.” [1P]
} 
Powyższy tekst ma charakter wartościujący i zawiera presupozycję: przynależność do grupy subkulturowej wiąże się bądź z byciem ofiara, bądź z naruszaniem prawa przez członków tej grupy (podkreślenie). Potwierdza to kolejny fragment powyższej wypowiedzi, choć ostanie zdanie ma tu charakter tonujący.

Tylko w jednym z badanych podręczników odnaleźć można tekst podający w wątpliwość dominującą tezę o wszechogarniającej nas przestępczości nieletnich:

„Prognozy przestępczości, opracowywane w latach 90-tych przez Komendę Główną Policji, przewidywały szybki rozwój przestępczości młodych ludzi. Atmosferę zagrożenia potęgowały media, przedstawiając przykłady szczególnie brutalnych przestępstw. Analizy statystyczne potwierdzają wzrost przestępczości nieletnich. W roku 2010 nieletni dokonali 100425 czynów karalnych w porównaniu z 76442 takich czynów w roku 2000, a procentowy udział w ogólnej liczbie stwierdzonych przestępstw wzrósł z $6-8,7 \%$. Istotnie wzrosła jedynie liczba przestępstw związanych z przemocą (...). Sami policjanci przyznają, że dane na temat liczby przestępstw mogą tworzyć nieco mylący obraz. W rzeczywistości w konflikt z prawem wchodzi tylko nieznaczny odsetek młodych ludzi. Wśród dzieci i młodzieży w wieku 13-17 lat wynosi on ok. 1,7\% ogółu populacji osób w tym wieku, wśród dzieci w wieku do 13 lat $-0,8 \%$. (Na podstawie statystyk KGP)" [1P]

\section{Analiza schematów argumentacyjnych}

Powyższą analizę strategii dyskursywnych należałoby wzbogacić o pogłębioną analizę schematów argumentacyjnych charakterystycznych dla badanych dyskursów. Ze względu na rozmiary tekstu nie jest możliwe przedstawienie szczegółowych analiz, a jedynie pewnych jej elementów, które pozwolą choćby w części na uzasadnienie sformułowanych wniosków. Na wstępie warto jednak przypomnieć, że wśród schematów argumentacyjnych wyróżnić można:

- toposy - czyli wiarygodne schematy argumentacyjne, które stanowią łącznik prowadzący od przesłanek argumentacji do jej konkluzji oraz

- błędne założenia - czyli schematy argumentacyjne naruszające reguły racjonalnej i wiarygodnej argumentacji (Reisigl, 2011, s.180).

Analiza dyskursu odnoszącego się do przestępczości nieletnich, zawartego w badanych podręcznikach, pozwala na wyróżnienie podstawowego toposu, jakim jest topos zagrożenia, który można sparafrazować za pomocą sformułowania: jeśli istnieje zagrożenie, należy mu przeciwdziałać. Kolejne, bardziej precyzyjne dla badanych tekstów, ale łatwo identyfikowalne schematy argu- 
mentacyjne odnoszą się do wzrastającej przestępczości młodzieży. Można je sparafrazować następująco:

1. Ponieważ wzrasta przestępczość młodzieży, należy temu przeciwdziałać.

2. Żeby zapobiec wzrostowi przestępczości młodzieży, należy obniżyć wiek ponoszenia odpowiedzialności karnej.

3. Żeby zapobiec wzrostowi przestępczości młodzieży, należy przede wszystkim kształtować motywację interesowną do przestrzegania prawa.

Schemat pierwszy jest szczególnie problematyczny w ocenie. Opiera się bowiem na założeniu, którego nie możemy uznać za fałszywe, jednakże przedstawione wyżej analizy strategii dyskursywnych wskazują, że argumentacja zastosowana dla uzasadnienia tezy dotyczącej wzrostu przestępczości młodzieży pozostawia wiele do życzenia. Jest w wielu momentach nielogiczna, niepoprawna pod względem interpretacyjnym, co w rezultacie zniekształca wizerunek młodzieży i demonizuje problem.

Kolejne dwa schematy (2 i 3) zdecydowanie nie są toposami. Przekraczają bowiem ramy racjonalnej i wiarygodnej argumentacji, odwołując się do argumentum ad populum. Przykłady obecności owych schematów argumentacyjnych przedstawione zostały w tabeli 2 .

Tabela. 2. Schematy argumentacyjne $w$ tekstach na temat przestępczości - podręczniki WOS, etap ponadgimnazjalny, zakres podstawowy

\begin{tabular}{|c|c|c|}
\hline Lp. & Przykład & Schemat argumentacyjny \\
\hline 1 & $\begin{array}{l}\text { Czy, twoim zdaniem, odpowiedzialność karna za popełnione zbrod- } \\
\text { nie powinna dotyczyć również osób, które ukończyły } 13 \text { lat? Uzasad- } \\
\text { nij swoją opinię.[2P] } \\
\text { Pytanie umieszczone pod rozdziałem zatytułowanym - Problem } \\
\text { przestępczości w Polsce (w którym za pomocą różnego rodzaju stra- } \\
\text { tegii dyskursywnych konstruuje się negatywny i stereotypowy obraz } \\
\text { młodzieży) }\end{array}$ & $\begin{array}{l}\text { Żeby zapobiec wzrostowi } \\
\text { przestępczości młodzieży na- } \\
\text { leży obniżyć wiek ponoszenia } \\
\text { odpowiedzialności karnej. }\end{array}$ \\
\hline 2. & $\begin{array}{l}\text { Określ czy preferencje większości respondentów dotyczące karania } \\
\text { nieletnich zgadzają się ze stanem prawnym obowiązującym w Pol- } \\
\text { sce. Swoje zdanie uzasadnij. [3P] } \\
\text { Polecenie umieszczone pod rozdziałem dotyczącym odpowiedzial- } \\
\text { ności nieletnich i bezpośrednio po tabelą, w której przedstawiono } \\
\text { wyniki sondażu CBOS, w który respondenci odpowiadali na pytanie } \\
\text { dotyczącego wieku, od którego - ich zdaniem dzieci powinny odpo- } \\
\text { wiadać tak samo jak dorośli }\end{array}$ & $\begin{array}{l}\text { Żeby zapobiec wzrostowi } \\
\text { przestępczości młodzieży na- } \\
\text { leży obniżyć wiek ponoszenia } \\
\text { odpowiedzialności karnej. }\end{array}$ \\
\hline 3. & $\begin{array}{l}\text { Wykrywalność przestępstw popełnionych w szkołach była bardzo } \\
\text { wysoka - w } 2010 \text { roku wyniosła } 93 \% \text {. Oznacza to, że w ponad } 9 \text { na } \\
10 \text { przypadków sprawca przestępstwa w szkole został złapany)[3P] }\end{array}$ & $\begin{array}{l}\text { Żeby zapobiec wzrostowi prze- } \\
\text { stępczości młodzieży należy } \\
\text { przede wszystkim kształtować } \\
\text { motywację interesowną do } \\
\text { przestrzegania prawa. }\end{array}$ \\
\hline
\end{tabular}


Tabela. 2. Cd.

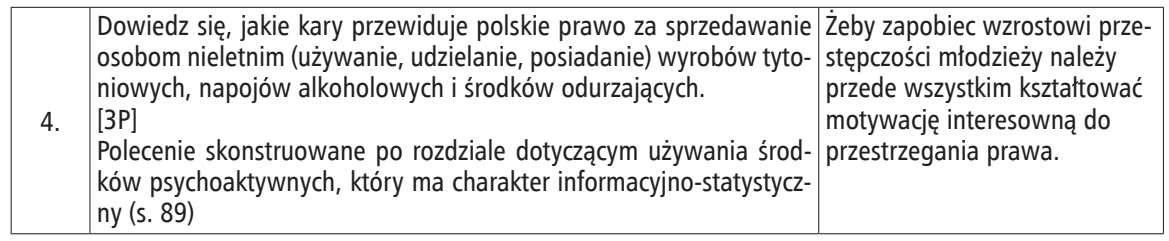

Należy jednak zwrócić uwagę, że przykłady te są jedynie wycinkiem tekstu, na podstawie którego wnioskujemy o istnieniu schematu. Co prawda starano się tu wybrać fragment kluczowy, a dodatkowo umieszczono krótki komentarz na temat jego lokalizacji w tekście, niemniej jednak - bez analizy kontekstowej konstruowanego pytania, polecenia czy wypowiedzi, trudno uchwycić jej orzekający sens. Dlatego też istotny jest chociaż dodatkowy komentarz. I tak, przykład 1 (tab. 2), to sugerujące pytanie, którego rzeczywisty charakter jest możliwy do odczytanie w zestawieniu z charakterem dyskursu konstruowanego w poprzedzającym go rozdziale. Liczne przykłady orzekania, stereotypizującego przypisywania cech negatywnych młodzieży, argumentowania stwarzającego pozory rzetelności, a w rzeczywistości zniekształcającego wizerunek poprzez manipulowanie i/lub niepoprawną interpretację danych nie pozostawiają złudzeń. Jeżeli dołączymy do tego rozdział dotyczący odpowiedzialności nieletnich oraz unikania sytuacji, w których można stać się ofiarą przestępstwa, a nadto zwrócimy uwagę na podsumowanie rozdziału, wówczas sugerujący charakter polecenia zawartego w przykładzie 1 (tab. 2) jest oczywisty. Obniżenie wieku karania jawi się tu jako rozwiązanie problemu przestępczości wśród młodzieży. Dodatkowo należy podkreślić, że w rozdziale poprzedzającym pytanie nie wyjaśniono pojęcia zbrodnia. Termin ten może zatem zostać nieprawidłowo zrozumiany (np. utożsamienie z każdym przestępstwem), a przez to wprowadzać w błąd.

Rozpatrywanie drugiego przykładu (tab. 2) musi również uwzględniać jego kontekst.

Rozdział zatytułowany „Przestępczość nieletnich”, w którym podobnie, jak w analizowanym wcześniej przykładzie 1, zidentyfikowano takie strategie dyskursywne jak: orzekanie, stereotypizacja, manipulowanie danymi, stanowi kontekst dla oceny skonstruowanego polecenia. Negatywny obraz młodzieży wzmocniony został dodatkowo przez umieszczenie podrozdziału na temat poczucia bezpieczeństwa, w którym wyeksponowano wzrastające poczucie zagrożenia badanych oraz wysoki odsetek osób będących zwolennikami kary śmierci. 
Nadto, jak zaznaczono w tabeli 2, polecenie umieszczono bezpośrednio pod tabelą, z której wynika, że spory odsetek respondentów życzyłby sobie obniżenia wieku, w którym dzieci mogłyby ponosić taką samą odpowiedzialność karną jak dorośli.

Należy w tym miejscu dodać, że tylko w jednym z badanych podręczników [4P] zidentyfikowano tekst poddający w wątpliwość wiarygodność drugiego schematu argumentacyjnego. Chodzi o ćwiczenie, którego polecenie dotyczy wyrażenia opinii na temat: Czy należy surowiej karać nieletnich przestępców? W ramach tego ćwiczenia zamieszczono dwa głosy z internetowego forum dyskusyjnego. Jeden z uczestników internetowej dyskusji opowiadał się za obniżeniem wieku ponoszenia odpowiedzialności karnej przez nieletnich, drugi - przeciw. Co prawda wspomniany fragment nie ma charakteru tekstu głównego i również obarczony jest cechami stereotypizującymi, ale jako jedyny zwraca uwagę na nieoczywistość tego, co wydaje się pewnikiem i dominuje w dyskursach na temat rozwiązania problemu przestępczości (tu: wśród młodzieży).

Przykłady 3 i 4 (tab.2) wpisują się w schemat argumentacyjny parafrazowany następująco: Żeby zapobiec wzrostowi przestępczości młodzieży należy przede wszystkim ksztaltować motywację interesowna do przestrzegania prawa. Według Sławomiry Wronkowskiej, o motywacji interesownej mówimy wtedy, gdy do przestrzegania prawa adresatów skłania obawa przed sankcją zinstytucjonalizowaną, w przeciwieństwie do motywacji bezinteresownej, która odwołuje się do innych motywów, sankcji rozsianej, akceptacji treści danej normy, przekonania o jej słuszności (Redelbach, Wronkowska, Ziembiński, 1994, s. 235) . Motywacja do przestrzegania prawa jest mocno powiązana z dominującą koncepcją prawa. Dominacja motywacji interesownej oznacza koncentrację na sferze behawioralnej, a nie emocjonalnej. Liczy się zatem fakt przestrzegania prawa, a nie przekonanie o jego słuszności. Z tym właśnie rodzajem motywacji łączy się oportunistyczna postawa wobec prawa.

Analiza dyskursu zawartego w podręcznikach do wiedzy o społeczeństwie dla czwartego etapu edukacyjnego doprowadza do jednoznacznego wniosku - zdecydowanie mamy tu do czynienia z dominacją motywacji interesownej, a często jest to jedyny rodzaj motywacji, na który zwraca się uwagę. Eksponowanie tej motywacji wpisuje się również w przytoczony wcześniej schemat argumentacyjny. Oba przykłady (3 i 4 - tab. 2) eksponują prawne konsekwencje popełnionych czynów. 


\section{Wnioski}

Krytyczna analiza dyskursów na temat przestępczości pozwoliła na skonstruowanie następujących wniosków;

1. W analizowanych dyskursach obecny jest topos szerzącej się przestępczości nieletnich. Wśród szczegółowych schematów argumentacyjnych można wyróżnić zarówno wiarygodne, jaki i nieracjonalne, odwołujące się do argumentacji populistycznej. Te ostatnie koncentrują się zwłaszcza na sankcjach karnych. Obniżenie wieku karania, ,zaostrzenie” odpowiedzialności nieletnich i grożenie sankcjami to sugerowane bądź artykułowane wprost rozwiązania, które stanowią antidotum na zjawisko przestępczości młodzieży.

2. Problematyczny jest też sposób konstruowania wizerunku młodzieży. Mimo że opiera się on na prawdziwej przesłance wzrostu przestępczości, jest wyolbrzymiony, przejaskrawiony, a w rezultacie fałszywy. Wizerunek młodzieży wykazuje cechy depersonalizacji, dyskurs operuje stereotypami, nieuprawnionymi generalizacjami i ma charakter negatywnie wartościujący. Problem przestępczości młodzieży wydaje się zjawiskiem ogromnych rozmiarów, dużo większym niż wskazują na to dane. Dyskryminujący charakter ma dobór i selekcja danych, które popierają tezę o rosnącej przestępczości nieletnich. Argumentacja stwarzająca pozory obiektywnej i rzetelnej w rzeczywistości obarczona jest wieloma błędami, takimi jak utożsamianie ze sobą zmiennych, które nie są tożsame (np. ,przestępstwo” i ,czyn karalny”), nieprawidłowa interpretacja wyników, wprowadzający w błąd opis przedstawianych danych, brak źródeł cytowanych danych. Ta manipulacyjna praktyka doprowadza do określonego celu. Celem tym jednak nie jest ukazanie rzeczywistych rozmiarów zjawiska, ale zniekształcenie wizerunku młodzieży za pomoca „,dopasowania” danych do stereotypowego obrazu. Dlatego oprócz odpowiedniej selekcji i doboru danych dyskursy operują liczbami. Ma to charakter wzmacniający. Gdy czytamy o setkach, tysiącach czy dziesiątkach tysięcy popełnianych przestępstw, oddziałuje to na naszą wyobraźnię zupełnie inaczej niż wtedy, gdy zdajemy sobie sprawę, jaki to stanowi procent ogólnej liczby popełnianych przestępstw. Wzmacniający charakter mają również polecenia, pytania, które, umieszczane pod tekstem głównym, eksponują jakąś określoną wybraną jego część, bądź też sugerują określoną odpowiedź stwarzając pozory możliwości swobodnej wypowiedzi. 
3. W analizowanych tekstach zidentyfikowano fragmenty, które mają charakter krytyczny, podważają rozpowszechnione stereotypy i poddaja dyskusji populistyczne schematy argumentacyjne. To bardzo cenne. Niestety, to tylko pojedyncze fragmenty, dlatego też trudno określić je mianem dyskursu. Być może szersza analiza podręczników (wykraczające poza przyjętą w tym artykule tematykę) pozwoliłaby na wyodrębnienie dyskursów krytycznych, transformujących. W odniesieniu do analizowanej tematyki przestępczości byłoby to jednak nieuprawnione.

4. Dominujące cechy analizowanych dyskursów wpisują się w model transmisyjny edukacji prawnej, w którym prawo jest ujmowane deterministycznie i należy go przede wszystkim przestrzegać. Interesujące jest natomiast to, że owo przestrzeganie prawa nie jest uzasadniane jego określoną wartością, czy funkcjami, jakie pełni w społeczeństwie, ale groźbą sankcji i to głównie karnych.

Uzyskane wnioski nie są jednak wystarczające do tego, by potwierdzić hipotezę o marginalizacji kompetencji krytycznych i emancypacyjnych w sferze edukacji prawnej obywateli, ale też nie zaprzeczają temu założeniu. Dyskursy mają tu z pewnością charakter adaptacyjny (a rzeczywistość, do której adaptują, jest zniekształcona), choć potrzebna jest weryfikacja ich cech dominujących na poziomie innych obszarów tematycznych.

\section{Bibliografia}

Borucka-Arctowa M., Skapska G. (1993), Teoretyczne problemy socjalizacji prawnej, [w:] M. Borucka-Arctowa, Ch. Kourilsky (red.), Socjalizacja prawna, Agencja Scholar, Warszawa.

Chomczyńska-Rubacha M., Pankowska D. (2011), Władza, ideologia, socjalizacja. Polityczność podręczników szkolnych, [w:] M. Chomczyńska-Rubacha, D. Pankowska (red.), Podręczniki i poradniki. Konteksty, dyskursy, perspektywy, Oficyna Wydawnicza „Impuls", Kraków.

Czarnota A. (2006), Dwa wymiary postkomunistycznej transformacji i panowania (złego) prawa. Esej na pograniczu socjologii i teorii prawa, [w:] A. Jamróz, S. Bożyk (red.), Z zagadnień współczesnych społeczeństwa demokratycznych, Temida2, Białystok.

Kopińska V. (2012), Edukacja prawna z perspektywy humanistyczno-krytycznej, „Rocznik Andragogiczny"

Łukaszewski W.(1984), Szanse rozwoju osobowości, Książka i Wiedza,Warszawa

Redelbach A., Wronkowska S. (1994), Ziembiński Z., Zarys teorii państwa i prawa, Wydawnictwo Naukowe PWN, Warszawa. 
Reisigl M. (2011), Analiza retoryki politycznej, [w:] R. Wodak, M. Krzyżanowski (red.), Jakościowa analiza dyskursu w naukach społecznych, Oficyna Wydawnicza Łośgraf, Warszawa.

Reisigl M. (2010), Dyskryminacja w dyskursach, tłum. D. Przepiórkowska, ,Tekst i Dyskurs" nr 3, www.tekst-dyskurs.pl/tid_3.htmlý [dostęp 19.08.2013].

Reisigl M., Wodak R. (2001), Discourse and Discrimination. Rhetorics of Racism and Anti-Semitism, Routledge, London.

Ustawa z dnia 26 października 1982 roku o postępowaniu w sprawach nieletnich, t.j. Dz. U. z 2010 r., Nr 33, poz. 178 ze zmianami.

Van Leeuwen T. (2005), Introducing Social Semiotics, Routledge, London/New York.

\section{The Image of Young People in Discourse about Juvenile Criminality in the Textbooks of Civic Education at the Upper Secondary Level}

\section{Summary}

The aim of this paper is showing how the image of youth and criminality is constructed within the discourses relating to juvenile criminality contained in the textbooks of civic education. Application of the method of critical discourse analysis allowed the identification of a number of discursive strategies and to highlight the most important argumentative schemes. It concluded that the image of young people resulting from the analyzed discourses has the features of depersonalization, and the discourse operates stereotypes, unwarranted generalizations and it is negative evaluative. The problem of youth criminality seems to be a phenomenon of enormous size, much larger than it is indicated by the data. Arguments which creates a semblance of objectivity and reliability is fraught with many mistakes in fact, and among specific argumentation schemes are identifiable those that refer to the argumentum ad populum. Discourse is a highly adaptive with an emphasis on self-interested motivation to obey the law. These conclusions are important in the context of education. Because discourses are some resources for the representation of reality, create a framework for meaning of this reality, so the question about the shape of school legal education seems to be important in this context. Citizenship activity, strongly emphasized and stressed in the context of civic competence, does not seem to relate to legal education. Here the threatening, frightening are present and the opportunist attitude towards the law is exposed.

Keywords: critical discourse analysis, textbooks, youth, criminality, civic education. 
